Insight, part of a Special Feature on Pathways to Resilient Salmon Ecosystems

\title{
The Social Construction of Fishing, 1949
}

\author{
Carmel Finley $^{1}$
}

\begin{abstract}
The theoretical construction known as maximum sustained yield (MSY) exists in three realms: as science, as policy, and as a legal concept. Despite substantial criticism by scientists and economists, MSY remains at the heart of fisheries science and fisheries management. This paper suggests that its institutional resilience springs more from its policy and legal roles than from its scientific strength. Maximum sustained yield was adopted as the goal of American fisheries policy in 1949. Between 1949 and 1955, the State Department pushed for its adoption internationally. In this paper, I first look briefly at the relationship between fishing and foreign policy goals during this period. Second, I look at how fishing was understood during 1949, when the American High Seas Fishing Policy was adopted. Third, I look at the actions of the 1955 International Technical Conference on the Conservation of the Living Resources of the Sea and how American actions shaped the development of fisheries science and the modern fishery management process.
\end{abstract}

Key Words: fisheries history; fisheries management; Milner B. Schaefer; salmon; surplus production theory; Wilbert M. Chapman; William C. Herrington

\section{INTRODUCTION}

There is a large body of scientific and economic thought that is critical of maximum sustained yield (MSY) as the objective of fisheries management (Larkin 1977, McGoodwin 1990, Bottom 1997, Pauly and Maclean 2003, Roberts 2007). Yet MSY remains at the heart of fisheries science and fisheries management and is firmly entrenched in legal and policy documents, treaties, and commissions. Although it has been modified (altered from maximum harvest to optimum harvest), such constrictions are recent and do not substantially alter the thrust of the policy, which has been to justify relatively high harvests. This entrenchment of MSY in policy, scientific, and legal mandates has made it more difficult for scientists and policy makers to implement policies that will enhance resilience in ocean ecosystems (Pauly 1994, Healey 2009).

The analysis of the failures of MSY has tended to come from scientists and economists, who have looked at the problems in relative isolation, trying to "fix" the science and ignoring the political context in which the science was developed (Finlayson
1994). My analysis looks at the post-World War II context in which MSY was shaped and the political forces that resulted in its adoption as the goal of international fisheries management in 1955. Between 1945 and 1958, fisheries concerns were tightly coupled with foreign policy for many countries, as fishing boats were a source of territorial claims in a world that officially upheld the freedom of the seas and limited coastal waters to 3 miles ( 4.8 $\mathrm{km})$.

It took fisheries scientists until the 1930s to prove scientifically that the Victorian scientist T. S. Huxley had been incorrect when he said that the great sea fishes were inexhaustible and that it was futile to try to regulate the great fisheries. During this period, scientists worked to formulate strategy of what would constitute "rational fishing," where both fish stocks and fishermen would be managed together (Kyle 1905, Thompson 1936, Russell 1942, Graham 1943, Sharp 1995). The adoption of MSY diverted scientists from this conversation, focusing the science on estimating critical harvest points, where the catch would be maximized yet sustained (Smith 1994). 
Maximum sustained yield essentially reflects the idea that the fish and the ocean system are infinitely resilient, an assumption that facilitated the enormous expansion of global fishing after World War II. It further postulates that scientists will be able to correctly estimate the critical points, where the greatest number of fish are at their maximum growth, a harvest level that can be sustained.

Maximum sustained yield also embedded a number of anthropogenic ideas (Lichatowich 1999) about fish abundance (Huxley 1883, Stone 1884). The ocean was essentially unchanging, implying steady states or equilibrium in fish populations (Francis 1980). Fishing, which was seen as part of the total mortality that fish faced, played a role in maintaining the equilibrium by removing older fish, freeing up resources for young fish that grow faster. If a stock was overharvested, fishing pressure could be relaxed and the stock would recover to previously high levels.

It also reflects an agricultural model of conservation, and a belief that fish populations are malleable and can be controlled for human benefit (McEvoy 1988) and that the oceans can be reordered to produce high-value species. Fish were widely transplanted and hatcheries offered the promise of restoring depleted stocks, especially for salmon (Oncorhynchus spp., Salmo spp.), but also for such ocean species as plaice (Pleuronectes platessa) (Shelbourne 1971). With the discovery of the Oregon Moist Pellet and improved hatchery survival during the 1950 s, scientists assumed that the limiting factor in unlimited salmon production - juvenile survival - had been surmounted (Hublou et al. 1959). The ocean "pasture" was unlimited in its ability to rear salmon in such numbers that most of the fish were "surplus" to what was needed to provide eggs for propagation.

Hatchery expansion in the Pacific Northwest occurred during a period of favorable survival conditions for West Coast salmonids, but also a period of intense pressure to produce more fish for social reasons. Under such conditions, hatcheries became politically acceptable symbols of more fish (Scarnecchia 1988). They ensured that whereas the stocks were conserved under MSY, there would still be plenty of fish for growing numbers of fishers and anglers. Thus, MSY offered a scientific basis for management that met multiple political and economic objectives.

\section{American Hegemony in Science}

There is a growing body of literature about American hegemony in science after World War II, but most of it deals with interactions among Americans and European physicists (Doel 1997, Krige 2006). Other works concentrate on the development of American science during the Cold War (Leslie 1993) and the field of oceanography (Oreskes and Rainger 2000, Rainger 2001, Hamblin 2005).

In contrast, little scholarly attention has been given to the development of fisheries science in the postwar period, with the exception of a large number of studies on the collapse of Atlantic cod (Gadus morhua), (Finlayson 1994, Parsons and Beckett 1994, Hutchings and Myers 1995, Hannesson 1996, Wright 2001, Pope 2004, Hubbard 2006). Legal scholars have not seen the U.S. as being successful in transferring its post-war power into dominance in fishing (Hollick 1981, Scheiber 1989). But this legal analysis does not take into account the American role in the adoption of post-war fisheries science, or its influence in the development of the modern fisheries management process.

When examined within a larger context of American scientific influence after World War II, the U.S. was extremely successful in shaping both fisheries science and the fisheries management process. This is because fisheries issues were tightly tied to foreign policy concerns within the State Department between 1945 and 1958. Three American fisheries scientists, Wilbert McLeod Chapman (1910-1970), William C. Herrington (1903-1991), and Milner B. Schaefer (1913-1970), played significant roles in bringing fisheries science into the State Department. In the process, they decisively shaped the development of American fisheries science.

\section{FISHERIES AND AMERICAN FOREIGN POLICY}

The cornerstone of foreign policy during this period was open seas and open skies: for American planes, submarines, naval vessels, and fishing boats (Paterson 1992). The U.S. wanted a string of military bases throughout the Pacific and a fleet of American boats catching tuna (Thunnus spp.) in the Mandated Islands, where the Japanese had developed a fishery during the 1920s (Kishinouye 
1923, U.S. Navy 1944, Supreme Commander Allied Powers (SCAP) 1949, Schaller 1985).

These objectives were threatened by the territorial claims filed by Mexico and Latin American countries between 1945 and 1955. Peru, Chile, and Ecuador were moving aggressively to expand their territorial limits, threatening to impose restrictions on illegal whaling (Fraser et al. 1977, Tonnessen and Johnson 1982) and on American fishing for bait stocks (Wolff 1980). The Latin Americans claimed bait fish were overfished, but the U.S. responded there was no scientific evidence of overharvest (Wilbert M. Chapman to the American Tuna Association (ATA), 9 August 1950, ATA files, Box 27, Folder, "Fisheries Industries Advisors," Scripps Institution of Oceanography).

A State Department reorganization in 1944 resulted in responsibility for fisheries being placed in the commodity division of the economic branch. In a storm of protest, the industry argued that fisheries involved vital national interests, diplomacy, and international law. Industry representatives met in January 1944 in Los Angeles and created the Pacific Fisheries Congress to push for a greater voice within the State Department. Pacific Fisherman publisher Miller Freeman was chairman (Miller Freeman Papers, Box 5, Folder 36, University of Washington Special Collections).

The American fishing industry was under severe pressure. New England fishermen sought a tariff against fillets from Canada, Norway, and Iceland (Dewar 1983). In southern California, the tuna industry was concerned that tuna exports from Japan would destroy their markets, as Japanese tuna had during the 1930s. The West Coast salmon industry was worried about the return of the Japanese to the international waters of Bristol Bay, where they had fished for king crab (Paralithodes camtschaticus) and bottomfish during the 1930s. In early 1947, Secretary of State George Marshall approved the creation of an under-secretary advisor for the industry.

Wilbert McLeod Chapman was appointed in April 1948. Born in Kalama, Washington, Chapman graduated from the University of Washington in 1937 with a doctoral degree in ichthyology. He worked for various state and federal fisheries agencies before the war, when he was sent to the equatorial Pacific to help create a small fishery designed to provide fresh fish to military troops. He returned to his job as the Curator of Fishes at the California Academy of the Sciences in San Francisco, with a goal of expanding American fisheries into the Mandated Islands, the Marshall, Caroline, and Marianas. In 1948, he was named director of the School of Fisheries at the University of Washington. His State Department appointment was announced in the spring.

The most immediate crisis facing Chapman in Washington was the negotiation of a treaty with 11 European countries and Canada to regulate the depleted North Atlantic fisheries. With the collapse of the California sardines (Sardinops caerulea), American purse seine boats were pouring into the tuna fishery off Mexico, which wanted a fisheries agreement that would include license fees on the purse seine boats. A peace treaty was also being negotiated with Japan, but the question of where the Japanese would be allowed to fish was a significant sticking point (Scheiber 2001).

\section{FISHERIES SCIENCE AND DIPLOMACY}

Under Chapman, fisheries science became a tool of diplomacy within the U.S. State Department. Within months of arriving in Washington, Chapman crafted the U.S. High Seas Fisheries Policy. The policy goals were to reinforce the Truman Proclamation of 1945, to uphold the principle of the freedom of the seas, and to establish that fish stocks could be conserved without claiming expanded territorial limits (Watt 1979). The scientific foundation of the policy was MSY, which Chapman defined as making "possible the maximum production of food from the sea on a sustained basis year after year" (Chapman 1949).

The High Seas Policy was published in the Secretary of State Bulletin on 16 January 1949. A fisheries treaty with Mexico was signed on 25 January 1949. Three days later, on 28 January 1949, an agreement was signed to regulate the North Atlantic, establishing the International North Atlantic Fisheries Commission (INCAP). On 31 May 1949, a convention was signed with Costa Rica to create the Inter-American Tropical Tuna Commission (IATTC). The U.S. actions imposed a fisheries goal before discussions among scientists began. One of Chapman's goals was to avoid any international control over American fishing (Chapman 1949). 
All three treaties, and the two commissions they established, were to be managed to produce MSY. The High Seas Policy formalized what had been unofficial American fisheries policy since the days of Spencer Fullerton Baird and the creation of the U.S. Fish Commission (Allard 1978). The idea of harvesting the maximum was reinforced during World War II, when Secretary of the Interior Harold Ickes assumed control of fishing policy with the goal of maximum production for the war effort, a policy that accelerated the catch of both California sardines and Alaskan salmon (Cooley 1963, McEvoy 1986).

Chapman's High Seas Policy rested on an implied scientific formulation, yet the critical document was not published in a refereed scientific journal, but in the Bulletin of the Secretary of State. There are no formal references. The graph that supports the theory (Fig. 1) has no numerical scale on the axes. It is a theoretical construction with no quantitative dimension. There was no quantitative evidence given to demonstrate or otherwise justify its actual relation to nature.

However, the High Seas Policy offered the solution to several political problems. The Canadians were urging action to control the growing number of foreign boats fishing in the western Atlantic. They sought a treaty with the European nations, but the United States did not want to subject itself to a European convention (Rozwadowski 2002). The convention with Costa Rica allowed the establishment of a scientific investigation into the rapidly expanding American tuna fishery, addressing Latin American concerns about the overfishing of baitfish stocks (Wolff 1980).

The High Seas Policy also outlined the American preferred option for regulating fisheries through the creation of bilateral or multilateral commissions with limited authority. Chapman's model of management was the International Pacific Halibut Commission, established by Canada and the U.S. in 1923 to reverse the declines in the halibut (Hippoglossus stenolepis) stocks (Dunn 2002).

\section{CHAPMAN CONCEPT OF THE ROLE OF FISHING}

The idea of maximum harvest as a goal of fishing is based in a utilitarian philosophy that resources are to be used and that not to harvest is wasteful. It reflects progressive ideals of efficiency and expertise, where trained experts would be able to estimate when the maximum harvest had been attained (Hays 1959). It also reflects a growing industrialization of nature after 1920 as scientific concepts of industrial management were increasingly applied to natural resource systems in an effort to standardize and increase production (Josephson 2002). These concepts are also reflected in the statutory mandates of the U.S. Forest Service and the Bureau of Land Management (Cortner and Moote 1999). Holling and Meffe call pesticides, monoculture, fire suppression, and clearcutting "pathologies," used by managers to try to control the natural world (Holling and Meffe 1996).

The adoption of MSY was grounded in Cold War politics, but also in an anthropogenic approach to explaining the oceans (Holm et al. 2001) that saw the ocean in terms of essentially benign agricultural metaphors: it could be farmed, and we could raise as many fish as we needed in hatcheries. Wild fish were crops to be harvested (Bottom 1997, Bottom et al. 2009). Sending large nets across the bottom of the oceans was akin to plowing (Pauly et al.2002). Managers believed regulation should be light and that technology brought progress by making the natural world more efficient. If resources were overharvested, they could recover (Smith 1990). The goal of post-war science was not to establish how much of a resource could be harvested but to determine how to exceed natural limits (Hirt 1994, Robbins 1997).

Chapman believed that as the intensity of fishing on a stock increased, the reproductive capacity of the fish population also increased for reasons that scientists did not understand, perhaps because there was more food for the fish that were left or because there was less predation. He expressed the relationship in a dome-shaped curve:

The meaning of this curve is that for any particular population of fish there is an optimum point of fishing intensity which, if sustained, will yield the maximum crop of fish year after year. Less fishing is wasteful, for the surplus of fish dies from natural causes without benefit to mankind; more fishing is wasteful because it depletes the population and so results actually in a smaller crop (Chapman 1949).

The implication here seems to be an acknowledgement that fish populations fluctuate, 
Fig. 1. Chapman's graph, published in the U.S. High Seas Fisheries Policy, U.S. Department of State Bulletin XX: 69.

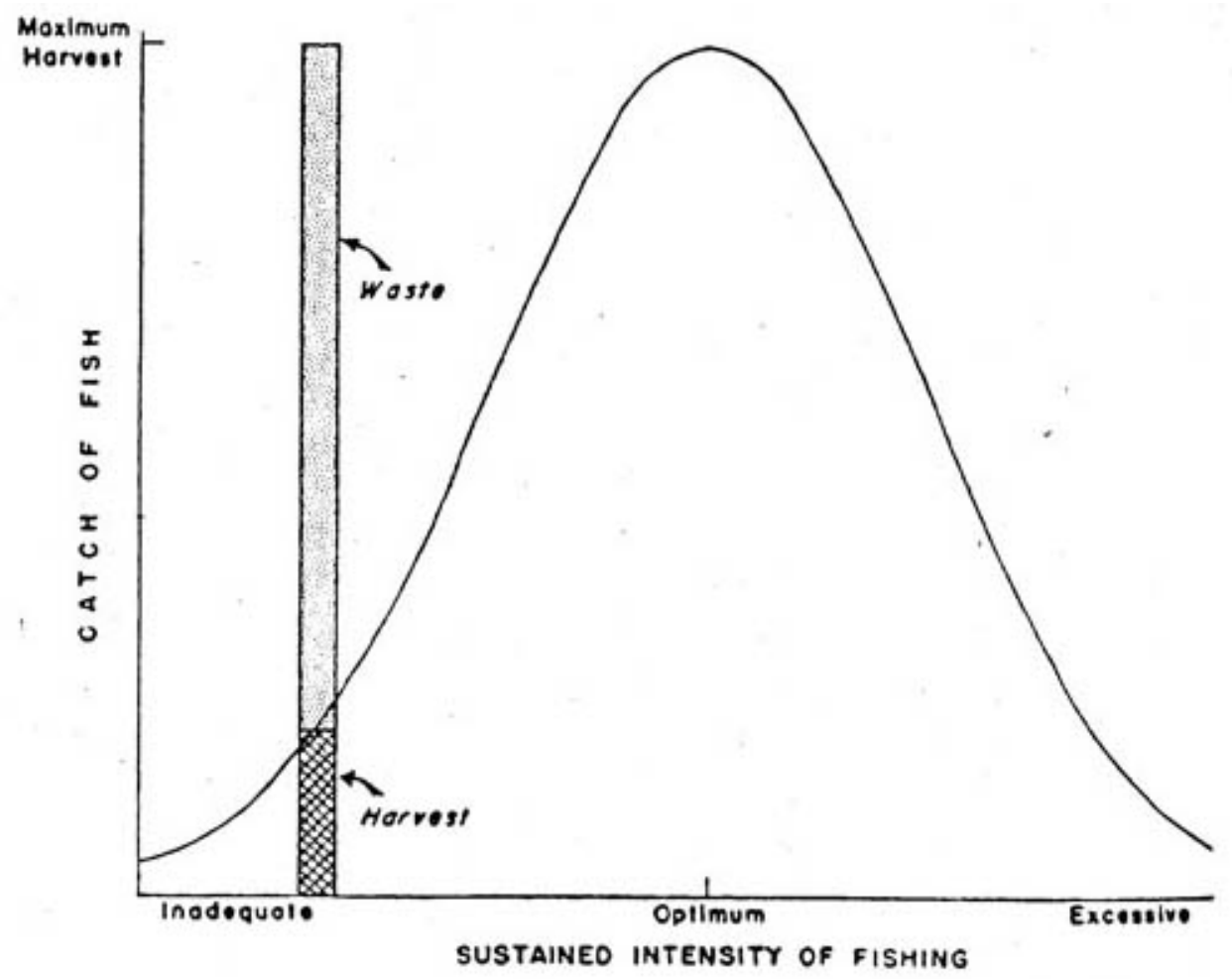

sometimes widely, but fishing produced the conditions that allowed the population to respond and produce the maximum amount of fish on a sustained basis, year after year.

In other words, fishing played an integral role in stabilizing fish populations. Just as American settlers in the $19^{\text {th }}$ century believed that the rain followed the plow, so Chapman seems to be saying that fishing created the conditions to produce more fish.

For Chapman, a key concept was that management was only necessary when fishing intensity passed the point of maximum return, a point that could only be determined by scientists (Pauly and Maclean 2003).

Chapman left the State Department in 1951, replaced by William C. Herrington, who had extensive experience with the New England fisheries during his years with the U.S. Fish and Wildlife Service before being sent to Japan to head the fisheries section of the Natural Resources Division of the SCAP. The SCAP was pushing for the resumption of Japanese whaling in Antarctica and the return of tuna boats to the Mandated Islands.

The international situation continued to cause problems for domestic fishermen. Mexican and South American countries seized American fishing boats in both the Atlantic and the Pacific. As tuna exports from Japan increased greatly during the early 1950 s, they pushed American tuna off the grocery store shelves. The southern California boats joined with New England fishermen in seeking tariff protection from imports. The State Department opposed all tariffs, based on foreign policy consideration of expanding trade with strategically important Japan and Iceland, where the U.S. wanted 
to maintain an air base. The American fishing industry was one of the nation's first sectors to have domestic jobs sacrificed for foreign policy considerations (Eckes 1992).

\section{SURPLUS PRODUCTION THEORY}

In 1953, the International Law Commission recommended that new ocean law was needed to deal with the escalating fisheries conflicts. It recommended that a new international body be created, under the auspices of the Food and Agricultural Organization (FAO) of the United Nations, with binding authority, and that territorial waters be expanded from 3 miles to 6 miles (4.8$9.7 \mathrm{~km})$. The U.S. opposed the recommendations, and in December of 1954, Herrington went to the United Nations and suggested that a technical conference be held in April to give guidance to the law commission, scheduled to meet in June in Geneva (speech by William C. Herrington, University of Rhode Island, 27 June 1966, American Tuna Association files, Box 29, unlabeled folder, Scripps Institution of Oceanography).

Three weeks before the conference started, on 27 March 1955, Ecuador seized two American flag fishing vessels, the Arctic Maid and the Santa Ana, off the Ecuadorian coast. An American seaman was seriously wounded by gunfire from the Ecuadorian patrol vessel. Fines of more than $\$ 49000$ were imposed on the vessel, despite strong American protests. Ecuador's ambassador to the U.S., Jose Chiriboga, apologized for the shooting, but said Ecuador was bound by the international agreement it had signed with Peru and Chile to take action to protect its maritime waters (State Department Memorandum of Conservation, 31 March 1955, Box 4142, 811.245, NARA RG 59). Tensions were high as the delegates headed to Rome.

The International Technical Conference on the Conservation of the Living Resources of the Sea was held between 18 April and 10 May 1955, at FAO headquarters in Rome. It was billed as a scientific meeting, but it was in fact a political one, focused on halting the escalating number of territorial claims being made against the industrial fishing nations (Hollick 1978, Beverton 1994). The American objective was to formulate a new set of recommendations for the law commission, scotching the ideas of expanding state territorial waters to 6 miles $(9.7 \mathrm{~km})$ and creating an international organization to give binding recommendations in settling fishing disputes (NARA, RG 59 Box 1538, 398.245, memorandum of conversation at Mexican Ministry for Foreign Relations, 31 March 1955).

The actions by the Latin Americans in seeking to create a regional $200-$ mile $(322-\mathrm{km})$ limit alarmed not only the U.S., but Britain as well, which was seeking to maintain its access to cod stocks off Norway, Iceland, and Newfoundland. Herrington began negotiations with the British during the summer of 1954 (record of Anglo-American Discussions on the Continental Shelf and Fishery Problems, Foreign Office, 22 July 1954, British Archives, FO 371/115380.)

As far as the U.S. was concerned, the technical conference was about much more than fish (draft instructions to the U.S. Delegation, William C. Herrington, 30 March 1955, papers of Edward Allen, Box 23, Folder "UN International Conference," University of Washington Special Collections). The U.S. did not want the conference to deal with territorial issues (Floyd McDougall to P.V. Cardon, 4 October 1954, unlabeled folder, FAO Files 14 FI 159 RG 14). Herrington traveled to Ottawa, Gothenburg, Oslo, Stockholm, and London during February 1955 for consultations (summary record of an informal meeting held in London on 9-10 February 1955, British Archives, FO 371/115380). He also traveled to Havana and Mexico City, and arrived in Rome a week before the meeting to consult with delegates from France, Greece, Panama, Turkey, and Nationalist China (Department of State Instruction, 28 March 1955, Box 1538, Folder 398.245, NARA RG 59).

Herrington crafted the agenda to showcase American fisheries science, specifically the work of Milner B. Schaefer, director of the IATTC, on the rapidly growing American tuna fishery in the Pacific. Schaefer presented two papers, the first suggesting an approach to fisheries research and the second detailing the spectacular success of the American tuna fishery off Latin America (Schaefer 1955a, b). During 1953, American boats had taken 274 million pounds of tuna, mainly off Peru, encapsulating one of the reasons why Latin Americans were so unhappy with the American fleet.

Schaefer's tuna paper reflects the two critical assumptions that were made at Rome: (1) the 
biological assumption that fish populations had "surplus" production that could safely be harvested and that scientists would be able to pinpoint these harvest targets, and (2) the economic assumption that when catches dropped, fishing would decline because it was no longer economic for fishing to continue. The fishery did not need to be regulated because free market forces controlled effort.

Schaefer's tuna paper featured his reconstruction of the tuna catch through the 1930s, from logbooks kept by fishermen. Schaefer had used the data to plot the catch, effort, and size distribution of yellowfin (Thunnus albacares). The yellowfin data (Fig. 2) generally show two clusters: a tight one in the data from 1934-1945, close to the rising arc of the dome-shaped curve, as the fish grew and put on weight. A second set of data points recorded the post-war catch, clustered near the peak of the curves, when the population is at its maximum. A critical omission was that Schaefer had been unable to find a way to age tuna.

Schaefer concluded that in 1953, yellowfin tuna appeared to be fished at near MSY levels, but danger of serious overfishing had decreased and construction of new vessels was not economically attractive (Schaefer 1955b). Schaefer's analysis fit an economic theory widely publicized in the 1930s, that fish stocks could not be exterminated because as soon as the fish were thinned and fishing was no longer profitable, fishing would decline, thanks to business failure (Taylor 1930). In other words, open markets would solve the biological problem, with no need for fishing restrictions. Skipjack (Katsuwonus pelamis) runs fluctuated greatly but, despite heavy fishing, showed no signs of decline. Fishing could substantially increase before reaching MSY levels.

Schaefer's curve clearly illustrated the argument he was making: fish had surplus production that could safely be harvested, and when the catch per unit effort (CPUE) dropped, fishing would slow and the stocks would be given time to rebound to optimal levels. Introducing restrictions as the catch was increasing was not necessary. The fishery could regulate itself.

Although surplus production theory purported to be based on biology, it rested on an economic trigger: a decline in the CPUE. In Schaefer's yellowfin example, economic conditions had halted the expansion of fishing. Therefore, the fishery was being managed at close to MSY levels and management intervention, in the form of restrictions to slow the catch, was not warranted. When the stocks had recovered to MSY levels, the fishing level could be increased. Subsequently, many scientists would question the validity of the second set of data points, and their fit to what would come to be called a Schaefer curve (McGoodwin 1990).

Schaefer's whole biological-economic model presumed that markets were open, when in fact they were not. Through the centuries, many fisheries had enjoyed subsidies of various sorts, such as bounties on the catching of cod in New England (Morison 1941). Especially after 1945, governments embarked on a series of subsidies for the fishing industry in most industrialized countries, including the U.S., Britain, Japan, and the Soviet Union. The scale and range of the subsidies varied, but substantial amounts of government money were invested into the fishing industries of most developed nations. The development of fisheries in poorer countries, through such programs as the FAO, also acted to subsidize fisheries development. Government programs subsidized the cost of building boats and processing facilities, and the development and marketing of new fish products, most through low-interest loans. Tariffs are also a form of subsidy, and various countries introduced protective measures to protect their fishermen from low-cost imports.

When fish catches fell, the economic incentive to leave the industry was neutralized by government actions. If anything, once government spending was established, subsidies continued, creating the pressure for more assistance, and continually thwarting the expected corrective action of the markets (Ludwig et al. 1993, Schrank 1998). In a truly sociologically flexible system, where fishermen could easily enter and leave fisheries to take other employment during bad times, this economic trigger might have worked. But the fisheries market was not open. Government subsidies (initiated for both domestic and foreign policy reasons) were extensive and expanding, and most fishermen had no other occupations to turn to when fishing was poor (Fisheries Research Board of Canada 1956, Vickers 1994).

As adopted in 1955, MSY meant that countries could not act to restrict fishing by foreign boats until it could be established scientifically that stocks were being depleted and the attainment of MSY 
Fig. 2. Schaefer's curve showing yellowfin tuna populations and the catch from 1934-1953 (Source: Schaefer 1955b).

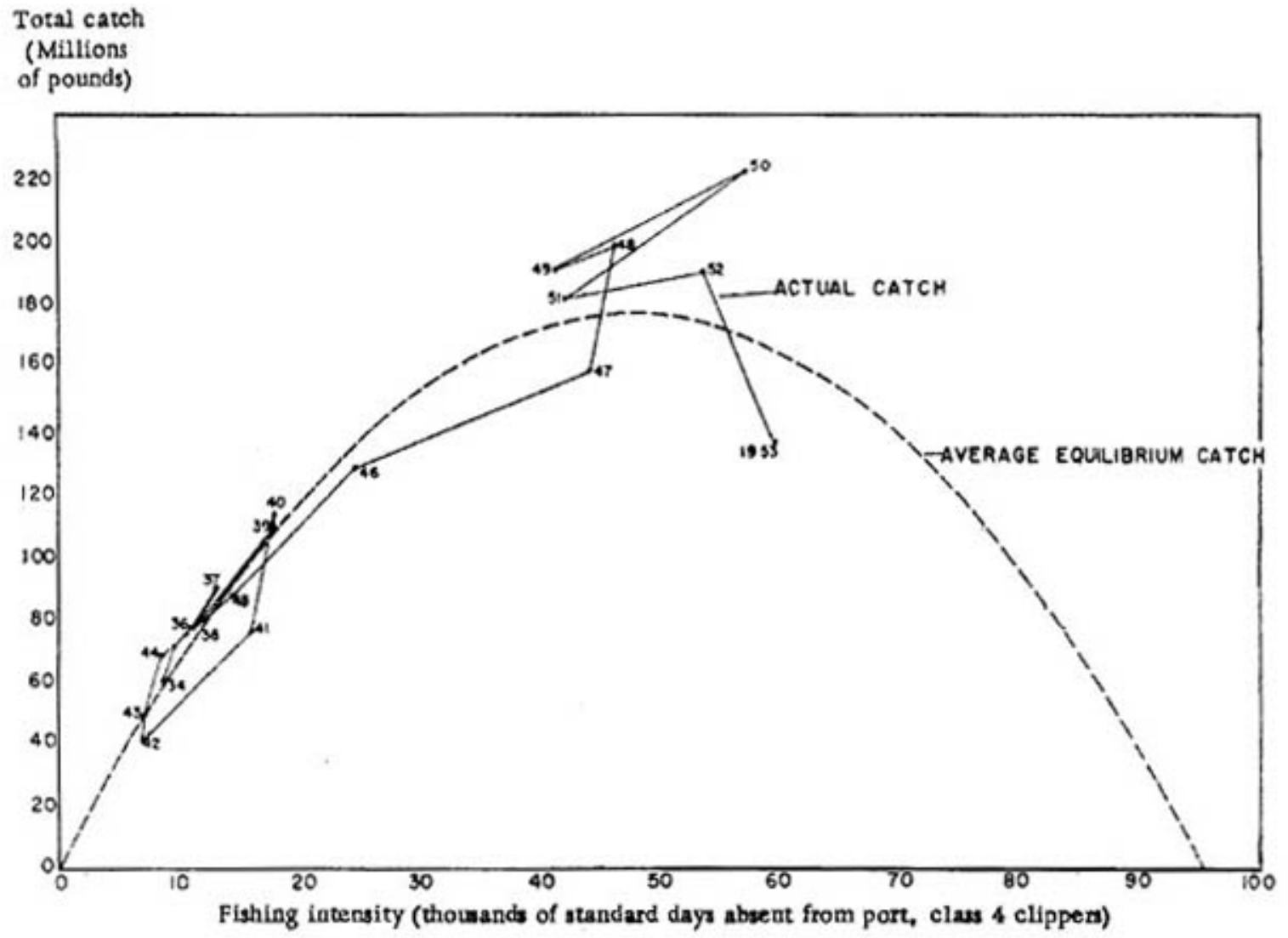

jeopardized (papers of D. B. Finn, misc. notes, 1955 Conference, Folder 14, FAO 14 FI 159 RG 14). This was a substantial burden of proof that smaller countries, such as Peru, Ecuador, and Chile, found difficult to meet.

By refusing to place restrictions on fisheries as they were being developed, the 1955 meeting justified the expenditure of government funds to expand fishing throughout the world's oceans. This government money contributed to overcapitalization, one of the most difficult problems in regulating fisheries (Christy 1997).

Another of the legacies of this 1955 meeting is the establishment of a pattern that is still repeated 60 years later, of taking fish without regulation until critical biological estimates have been reached. Measures to slow or halt fishing have mixed success in conserving stocks. The development of derby or Olympic fisheries have also had substantial social costs to fishermen and have increased costs to managers (Healey 1998)

American actions substantially shaped both the direction of fisheries science and the fisheries management process in three ways. First, the actions at Rome prevented the implementation of restrictions on fisheries as they were being developed. Second, the U.S. rejected any discussion of an international management organization with binding authority to regulate fishing and the territorial questions it raised, in favor of the creation of bilateral and multilateral commissions, generally 
with limited regulatory authority. Third, the U.S. influenced the institutionalization of the idea that fish stocks had "surplus" that could safely be harvested, paving the way for the development of derby fishing. This last factor assumed that scientists would soon have the ability to predict these critical harvest points - or MSY - and that effective action could be taken to rein in fishing.

The establishment of MSY has generally been interpreted as being a positive step for global fisheries as this science-based concept would result in the safe development of fisheries while sustaining stocks in perpetuity (Scheiber 1989, Hubbard 2006). Global fish catches increased by $6.8 \%$ a year through the 1950s (from 18.5 million $\mathrm{mt}$ in 1950 to 31.2 million in 1959), assuring policy makers and scientists that the adoption of MSY had been wise and prudent (Garcia and Newton 1994).

This perception of scientific management was strengthened by the publication in the early $1950 \mathrm{~s}$ of what biologist Tim B. Smith calls the three partial theories of MSY. The yield per recruit theory, by British scientists Raymond Beverton and Sidney Holt, dealt with estimating the maximum yield from each cohort of a fish population. The spawner and recruit theory, devised by Canadian William Ricker, estimated the optimum number of spawners for each year class of fish. Schaefer's surplus production theory estimated the maximum total harvest of fish every year from a standing population (Smith 1994). Smith wrote that the three theories came to dominate fisheries research for more than four decades but that biologists were unable to find a way to unify them into a comprehensive management regime. This "defined narrow terms of reference for the future study of fisheries biology," he wrote (Smith 1994).

I contend that the three partial theories could not be successfully unified in a comprehensive scientific theory because MSY was driven more by its policy concerns than by its science. The 1955 Rome meeting was described by its planners and participants as being "scientific and technical," designed to provide guidance to the International Law Commission. However, the meeting was a political one, held in response to actions by Latin American countries, seeking to restrict American fishing for baitfish. The American position was shared by several European nations, concerned that countries such as Iceland also were moving to restrict fishing by foreign boats.
Estimating MSY from the partial theories depends on high-quality data, which cannot be obtained from fisheries as they develop because regulations are prohibited until the fishery shows signs of overfishing. The MSY has to be exceeded before it can be established (Hilborn and Walters 1992). Policy makers showcased MSY and pushed for its adoption because it supported their objectiveupholding the freedom of the seas and the right of industrialized nations to continue to fish wherever their technology allowed them to do so.

The adoption of MSY was not unanimous. In particular, Britain's chief fisheries scientist, Michael Graham, argued vigorously during the planning for the Rome meeting and during the conference itself, that MSY was not an appropriate goal for fisheries management (Graham 1955). Graham argued the focus should be on "controlling man's activities so as to produce the maximum sustainable yield of products in a form most useful to man," (British Archives, MAF 209/32 summary record of an informal meeting held in London on 910 February 1955). D. B. Finn, head of the fisheries division of the FAO, which hosted the meeting, also opposed the MSY goal, arguing that it was a theoretical concept with no scientific agreement about its meaning. He thought it was not an appropriate goal for management (papers of D. B. Finn, FAO 14 Fl 159 RG 14, Folder April-May 1954 conference).

Finn assigned Sidney Holt, who had moved to the FAO in 1952, to write a critique of MSY and Schaefer's surplus production theory, but although the paper went through four drafts, it was not included in the conference's published documents. Holt argued against research aimed at estimating a "critical point" for ocean fishery management. He said the objective could only be met with an "infinitely high fishing intensity and hence at a correspondingly high cost; it is therefore a totally unreal objective for resource use" (papers of D. B. Finn, FAO 14Fl 159RG 14, Folder April-May 1954 conference, italics in the original). Holt meant that excess harvesting capacity would develop under an MSY scenario.

Graham argued in "The Fish Gate" that unlimited fisheries were unprofitable (Graham 1943). He had hired Beverton and Holt to pursue his hypothesis that a conservative fishing regime, with restrictions imposed early, produced a greater yield of fish and protected stocks that had not yet spawned (Beverton 
and Holt 1957). But at the Rome meeting, when it came time to vote on the structure and form of future fisheries science, the head of the British delegation, Minister of Fisheries Ronald Wall, supported the American position. Britain was also interested in its own line of fishing boats in foreign watersincluding Newfoundland and New England.

Graham's preferred course of action-the introduction of restrictions as a fishery was growing - could have supported the political positions of Peru, Ecuador, and Chile, which were attempting to control American bait fishing off their coasts. It also would have supported the position of Iceland, which had encouraged the United Nations to hold the conference in the first place.

After the Rome conference ended, Herrington and Chapman drove to Geneva, for the meeting of the International Law Commission. The ILC accepted the "technical advice" of the Rome meeting and MSY was adopted at the policy level in 1958. A theoretical concept, MSY is reinforced by its existence in multiple fields, first as policy, then as science, then as a legal construct adopted in national and international treaties. The criticism that was leveled at the adoption of MSY had dropped from sight and there have been no further attempts to create an international body with binding authority to rule in fisheries disputes. The overall shape of modern fisheries management was fixed at Rome on a scientific foundation that was distorted by political objectives and contained several untested assumptions about fish stocks.

\section{CONCLUSIONS}

Policy makers at Rome (and certainly some of the scientists) saw the science as being on the verge of not only understanding the ocean, but having a certain ability to control its processes. Man and his technology were benevolent forces in a hostile natural world. The Rome delegates approved three resolutions, including language that the immediate aim of conservation was to conduct fishing activities so as to increase, or at least sustain, the yield of fishing. "Scientifically sound" measures were also to be taken to improve the resource.

A critical misunderstanding at Rome was underestimating the fishing capacity of the fleet that was being built and overestimating the ability of fish to reproduce in the face of such enormous fishing pressure. The policy makers also assumed an open market, when in fact most of the countries involved were substantially subsidizing fisheries for a variety of social, political, and economic objectives.

The existence of MSY in multiple realmspolitically, scientifically, and legally-has reinforced its perception as being based in science rather than in policy. With the focus firmly on establishing harvest points for individual fish, our attention has been diverted away from the overall impact of fishing on ocean ecosystems. The failure of MSY to protect stocks has contributed to public disillusionment over the ability of scientists to manage resources.

Once established at the policy level, MSY proved to be resilient indeed. It became institutionalized and the early criticism of its scientific weaknesses was forgotten (Holt and Talbot 1978, Barber 1988). It has also been entrenched at a deeper level, where it has acted as a legal and political instrument that controlled scientific ideas about how nature works. This entrenchment at the legal, political, and philosophical levels has contributed to the persistence of MSY. But the establishment of MSY in the first place owed more to justifying a political and economic agenda than it did to sustaining fish stocks.

Responses to this article can be read online at: http://www.ecologyandsociety.org/voll4/iss1/art6/responses/

\section{Acknowledgments:}

Thank you to Sidney Holt, Jim Lichatowich, Tony Koslow, and Dan Bottom for discussions around this paper.

\section{LITERATURE CITED}

Allard, D. C. Jr. 1978. Spencer Fullerton Baird and the U.S. Fish Commission. Arno Press, New York, New York, USA.

Barber, W. E. 1988. Maximum sustained yield lives on. North American Journal of Fisheries Management 8(2):153-157. 
Beverton, R. J. H. 1994. The state of fisheries science. Pages 25-54 in $\mathrm{C}$. Voitlander, editor. The state of the world's fisheries resources. International Science Publisher, Lebanon, New Hampshire, USA.

Beverton, R. J. H., and S. J. Holt. 1957. On the dynamics of exploited fish populations. Chapman and Hall, London, UK.

Bottom, D. L. 1997. To till the waters: a history of ideas in fisheries conservation. Pages 569-597 in D. J. Stouder, P. A. Bisson, and R. J. Naiman, editors. Pacific salmon and their ecosystems: status and future options. Chapman and Hall, New York, New York, USA.

Bottom, D. L., K. K. Jones, C. A. Simenstad, and C. L. Smith. 2009. Reconnecting social and ecological resilience in salmon ecosystems. Ecology and Society 14(1): 5. [online] URL: http:// www.ecologyandsociety.org/vol14/iss1/art5/.

Chapman, W. M. 1949. United States policy on high seas fisheries. U.S. Department of State, Washington, D.C., USA. Bulletin XX:67-80.

Christy, F. 1997. Economic waste in fisheries: impediments to change and conditions for improvement. Pages 28-39 in E. K. Pikitch, D. D. Huppert, and M. P. Sissenwine. Global trends, fisheries management. American Fisheries Society, Bethesda, Maryland, USA.

Cooley, R. A. 1963. Politics and conservation: the decline of Alaska salmon. The Conservation Foundation, New York, New York, USA.

Cortner, H. J., and M.A. Moote. 1999. The politics of ecosystem management. Island Press, Washington, D.C., USA.

Dewar, M. E. 1983. Industry in trouble: the federal government and the New England fisheries. Temple University Press, Philadelphia, Pennsylvania, USA.

Doel, R. E. 1997. Scientists as policymakers, advisors, and intelligence agents: linking contemporary diplomatic history with the history of contemporary science. Pages 215-244 in Thomas Soderqvist, editor. The historiography of contemporary science and technology. Harwood Academic Publishers, Amsterdam, The Netherlands.
Dunn, R. J. 2002. William Francis Thompson (1889-1965) and his pioneering studies of Pacific halibut (Hippoglossus stenolepis). Marine Fisheries Review 63(2):5-14.

Eckes, A. E. 1992. Trading American interests. Foreign Affairs 71(4):135-54.

Finlayson, A. C. 1994. Fishing for truth: a sociological analysis of northern cod stock assessments from 1977-1990. Memorial University of Newfoundland, St. John's, Newfoundland, Canada.

Fisheries Research Board of Canada. 1956. The commercial fisheries of Canada. Department of Fisheries of Canada and the Fisheries Research Board, Ottawa, Ontario, Canada.

Francis, R. C. 1980. Fisheries science now and in the future: a personal view. New Zealand Journal of Marine and Freshwater Research 14(1):95-100.

Fraser, N., P. Jacobson, M. Ottoway, and L. Chester. 1977. Aristotle Onassis. Times Newspaper Limited, London, UK.

Garcia, S. M., and C. Newton. 1994. Current situation, trends, and prospects in world capture fisheries. Pages 3-27 in E. K. Pikitch, D. D. Huppert, and M. P. Sissenwine. Global trends, fisheries management. American Fisheries Society, Bethesda, Maryland, USA.

Graham, M. 1943. The fish gate. Faber and Faber Limited, London, UK.

- 1955. A first approximation to a modern theory of fishing. Pages 56-57 in Proceedings, International Technical Conference for the Conservation of the Living Resources of the Sea, 18 April-10 May 1955, Rome, Italy. United Nations Publications 1956, IIB1.

Hamblin, J. D. 2005. Oceanographers and the cold war: disciples of marine science. University of Washington Press, Seattle, Washington, USA.

Hannesson, R. 1996. Fisheries mismanagement: the case of the North Atlantic cod. Fishing News Books, Oxford, UK.

Hays, S. P. 1959. Conservation and the gospel of efficiency. Harvard University Press, Cambridge, 
Massachusetts, USA.

Healey, M. C. 1998. The paradox of fairness: the impact of escalating complexity on fisheries management. Marine Policy 22(2):109-118, 115.

Healey, M. C. 2009. Resilient salmon, resilient fisheries for British Columbia. Ecology and Society 14(1): 2. [online] URL: http://www.ecologyandsoc iety.org/vol14/iss 1/art2/.

Hilborn, R., and C. J. Walters. 1992. Quantitative fisheries stock assessment: choice, dynamics and uncertainty. Chapman and Hall, New York, New York, USA.

Hirt, P. 1994. A conspiracy of optimism: management of the national forests since World War II. University of Nebraska Press, Lincoln, Nebraska, USA.

Hollick, A. L. 1978. The roots of U.S. fisheries policy. Ocean Development and International Law Journal 5(1):61-105.

1981. U.S. foreign policy and the law of the sea. Princeton University Press, Princeton, New Jersey, USA.

Holling, C. S., and G. K. Meffe. 1996. Command and control and the pathology of natural resource management. Conservation Biology 10(2):328337.

Holm, P., T. D. Smith, and D. J. Starkey. 2001. Introduction. Pages xiii-xix in P. Holm, T. D. Smith, and D. J. Starkey. The exploited seas: new directions for marine environmental history. Memorial University Press, St. John's, Newfoundland, Canada.

Holt, S., and L. M. Talbot. 1978. New principles for the conservation of wild living resources. Wildlife Monographs 59.

Hubbard, J. 2006. A science on the scales: the rise of Canadian Atlantic fisheries biology, 1898-1939. University of Toronto Press, Toronto, Ontario, Canada.

Hublou, W. F., J. Wallis, T. B. McKee. D. K. Law, R. O. Sinnhuber, and T. C. Yu. 1959. Development of the Oregon Moist Pellet Diet. Research Briefs, Fish Commission of Oregon 7(1):28-56.
Hutchings, J. A., and R. A. Myers. 1995. The biological collapse of Atlantic cod off Newfoundland and Labrador. Pages 25-44, in R. Arnson and L. Felt, editors. The North Atlantic fisheries: successes, failures and challenges. University of Prince Edward Island Press, Charlottetown, Prince Edward Island, Canada.

Huxley, T. H. 1883. Inaugural address. Fisheries Exhibition Literature 4:1-22.

Josephson, P. R. 2002. Industrialized nature: brute force technology and the transformation of the natural world. Island Press, Washington, D.C., USA.

Kishinouye, K. 1923. Contributions to the comparative study of the so-called scombroid fishes. Journal of the College of Agriculture, Imperial University of Tokyo 8(3):293-475.

Krige, J. 2006. American hegemony and the postwar reconstruction of science in Europe. MIT Press, Cambridge, Massachusetts, USA.

Kyle, H. M. 1905. Statistics of the North Sea fisheries. Part III. Summary of the available fisheries statistics and their value for the solution of the problem of overfishing. Rapports, Conseil Permanent International pour l'Exploration de la Mer 3.

Larkin, P. A. 1977. An epitaph for the concept of maximum sustained yield. Transactions of the American Fisheries Society 106(1):1-11.

Leslie, S. W. 1993. The cold war and American science. Columbia University Press, New York, New York, USA.

Lichatowich, J. 1999. Salmon without rivers: a history of the Pacific salmon crisis. Island Press, Washington, D.C., USA.

Ludwig, D., R. Hilborn, and C. Walters. 1993. Uncertainty, resource exploitation, and conservation: lessons from history. Science 260(17):17-36.

McEvoy, A. F. 1986. The fisherman's problem: ecology and law in the California fisheries. Cambridge University Press, Cambridge, UK.

1988. Towards an interactive theory of 
nature and culture: ecology, production, and cognition in the California fishing industry. Pages 211-229 in D. Worster, editor. The ends of the earth: perspectives on modern environmental history. Cambridge University Press, Cambridge, UK.

McGoodwin, J. R. 1990. Crisis in the world's fisheries: people, problems and politics. Stanford University Press, Stanford, California, USA.

Morison, S. E. 1941. The maritime history of Massachusetts, 1783-1860. Houghton Mifflin Company, Boston, Massachusetts, USA.

Oreskes, N., and R. Rainger. 2000. Science and security before the atomic bomb: the loyalty case of Harold U. Sverdrup. Studies in the History and Philosophy of Modern Physics 31(3):309-369.

Parsons, L. S., and J. S. Beckett. 1994. Fisheries management in Canada: the case of Atlantic groundfish. Pages 73-79 in E. K. Pikitch, D. D. Huppert, and M. P. Sissenwine. Global trends, fisheries management. American Fisheries Society, Bethesda, Maryland, USA.

Paterson, T. G. 1992. On every front: the making and unmaking of the cold war. W. W. Norton and Company, New York, New York, USA.

Pauly, D. 1994. On the sex of fish and the gender of scientists. Chapman and Hall, London, UK.

Pauly, D., V. Christensen, S. Guenette, T. J. Pitcher, U. R. Sumaila, C. J. Walters, R. Watson, and D. Zeller. 2002. Towards sustainability in world fisheries. Nature 418:689-695.

Pauly, D., and J. Maclean. 2003. In a perfect ocean: the state of fisheries and ecosystems in the North Atlantic ocean. Island Press, Washington, D. C., USA.

Pope, P.E. 2004. Fish into wine: the Newfoundland plantation in the seventeenth century. University of North Carolina Press, London, UK and Chapel Hill, North Carolina, USA.

Rainger, R. 2001. Constructing a landscape for postwar science: Roger Revelle, the Scripps Institution of Oceanography, and the University of California, San Diego. Minerva 39:327-352.
Robbins, W. 1997. Landscapes of promise: the Oregon story: 1900-1940. University of Washington Press, Seattle, Washington, USA.

Roberts. C. 2007. The unnatural history of the sea. Island Press, Washington, D.C., USA.

Rozwadowski, H. M. 2002. The sea knows no boundaries: a century of marine science at ICES. University of Washington Press, Seattle, Washington, USA.

Russell, E. S. 1942. The overfishing problem. Cambridge University Press, Cambridge, UK.

Scarnecchia, D. L. 1988. Salmon management and the search for values. Canadian Journal of Fisheries and Aquatic Sciences 45(11):2042-2050, 2-44.

Schaefer, M. B. 1955a. The scientific basis for a conservation program. Pages 15-55 in Proceedings, International Technical Conference for the Conservation of the Living Resources of the Sea, 18 April-10 May 1955, Rome, Italy. United Nations Publications 1956, IIB1.

- 1955b. Scientific investigation of the tropical tuna resources of the eastern Pacific. Pages 194-221 in Proceedings, International Technical Conference for the Conservation of the Living Resources of the Sea, 18 April-10 May 1955, Rome, Italy. United Nations Publications 1956, IIB1.

Schaller, M. 1985. The American occupation of Japan: the origins of the cold war in Asia. Oxford University Press, Oxford, UK.

Scheiber, H. N. 1989. Origins of abstention doctrine in ocean law: Japanese-U.S. relations and the Pacific fisheries, 1937-1958. Ecology Law Quarterly 16:23-101.

-2001. Inter-allied conflicts and ocean law, 1945-1953: the occupation command's revival of Japanese whaling and marine fisheries. Institute of European and American Studies, Academic Sinica, Taipei, Taiwan.

Schrank, W. B. 1998. The failure of the Canadian seasonal fishermen's unemployment insurance reform during the 1960s and 1970s. Marine Policy 22(1):67-81. 
Sharp, G. D. 1995. It's about time: new beginning and old good ideas in fisheries science. Fisheries Oceanography 4(4):324-341.

Shelbourne, J. E. 1971. The Artificial Propagation of Marine Fish. Second edition. The Academic Press, Jersey City, New Jersey, USA.

Smith, B. L. R. 1990 American science policy since World War II. The Brookings Institute, Washington, D.C., USA.

Smith, T. 1994. Scaling fisheries: the science of measuring the effects of fishing, 1855-1955. Cambridge University Press, Cambridge, UK.

Stone, L. 1884. The artificial propagation of salmon in the Columbia River basin. Transactions of the American Fish Cultural Association 13:21-31.

Supreme Commander Allied Powers. 1949. Japan's natural resources, a comprehensive survey. Hosakawa Printing Company, Tokyo, Japan.

Taylor, H. F. 1930. Trends of progress in the fish industry. Canadian Fisheries Annual, Ottawa, Ontario, Canada.

Thompson, W. H. 1936. Conservation of the Pacific halibut, an international experiment. Smithsonian Institution, Washington, D.C., USA.

Tonnessen, J. N., and A. O. Johnsen. 1982. The history of modern whaling. R. I. Christophersen, translator. C. Hurst and Company and Australian National University Press, London, UK and Canberra, Australia.

U.S. Navy. 1944. The fishing industry of the Japanese mandated islands. Office of the Chief of Naval Operations, Washington, D.C., USA.

Vickers, D. 1994. Farmers and fishermen: two centuries of work in Essex County, Massachusetts, 1630-1830. University of North Carolina Press, Chapel Hill, North Carolina, USA.

Watt, D. C. 1979. First steps in the enclosure of the oceans: the origins of Truman's proclamation on the resources of the continental shelf, 28 September 1945. Marine Policy 3(3):211-224.

Wolff, T. 1980. In pursuit of tuna: the expansion of a fishing industry and its international ramifications-the end of an era. Arizona State University Press, Tempe, Arizona, USA.

Wright, M. 2001. A fishery for modern times: the state and the industrialization of the Newfoundland fishery, 1934-1968. Oxford University Press, London, UK. 